\title{
The Impact of Community Participation on Projects' Success in Africa: A Bottom Up Approach
}

\author{
George Stanley Kinyata (PhD), Nafiu Lukman Abiodun (PhD)* \\ Department of Economics and Statistics, Kabale University, Uganda \\ *Corresponding Author: Nafiu Lukman Abiodun (PhD), Department of Economics and Statistics, \\ Kabale University, Uganda
}

\begin{abstract}
This article studied the causes of the failure of many African development projects which were funded in 1980s and 1990s by Donors and implemented without involving local communities or beneficiaries of the projects. Lack of application of the bottom up approach to development in Africa and the failure of many funded projects is what the article is about. The article moves away from bringing governments close to the people to the bringing people close to government. Meaning that rather than imposing development projects on the community, its members should be involved and be allowed to participate in planning and execution of projects with governments. The article examines the extent to which the community participation contributes to success and sustainability of development projects in Africa. It analyses the benefits of the community participation and also studies why many projects were imposed on local communities without their participation and involvement in resource management as stakeholders and beneficiaries to reduce corruption and make their contribution for success and sustainability of these projects. The study shows how a lot of aid from developed countries came to Africa including Uganda in 1980s and 1990s for development projects but majority of them were not successful. Africa got nothing and some countries are still repaying the loans they got. The bottom up approach was not followed as shown in this article.
\end{abstract}

Keywords: Community; Project; Approach; Bottom Up.

\section{INTRODUCTION}

We should move from bringing governments close to the people to bringing people close to government (Igboeli, 1992). Rather than imposing development projects on the community, its members should be allowed to participate right from planning and execution of projects. This is the bottom-up approach to development planning which this article is about.

With scarce resources and the over increasing needs of the rural population where the majority of the people still live in Africa, we should not continue to plan for the people from the top or from the cities without their input. Community based development initiatives improve the match between what a community needs and what it obtains from development projects. Recently, the World Bank evaluation of projects indicated that those projects that have bottom up approach have succeeded and are rated satisfactory and sustainable (Olukotun,2017 and Stanley,2003). It is better to mobilize the society rather than leading it, because once the self-confidence in the people germinates, it will not take a long time for the flowers of development to blossom (Chirenje et al., 2013).

Community participation in project development is about ordinary citizens assessing needs and participating in project planning and budgeting, implementation and monitoring. This improves public resource management and reduces corruption.Thus, making civil servants and political leaders accountable to the people. The exemption of weak and powerless citizens from decision making is one of the causes of poverty, most especially in Uganda because it denies them their rights and creates unequal power relationship. Many countries except some countries like Uganda have addressed this problem by introducing a number of mechanisms to enhance community participatory budgeting at local levels.

Worldwide community participation is thought (Stone and Stone, 2010) and the work of practitioners is reflected in 'Agenda 21', the outcome document of the 1992 United Nations Earth Summit in Riode Janeiro, Brazil, highlighted stakeholder's participation as a major factor in promoting sustainable 
development. Since then, Agenda 21 has been given political, legal and regulatory force by national governments and by United Nations organizations in every area of human endeavor. The involvement of stakeholders ('participation') has now become a standard condition for approval or funding of many development projects. In some jurisdictions the right manifestation of the right of freedom of association and assembly. Countries such as the Netherlands, Germany, the USA and Swedenhave citizen participation and freedom of information provisions in their legal systems (Zillman et al., 2002).

According to research conducted by International Fund for Agricultural Development (Arthur and Michelle,2002) on knowledge for development effectiveness and project sustainability of Rural development projects in Asia, they asserted that development projects and programmes which include community participatory measures in project design obtain sustainable results especially those that take community commitment seriously and put it into practice with sound concepts, focused dedication, careful monitoring, and appropriate adaptive measures when necessary. Most successful programmes use bottom up planning to determine priorities and then accurately reflect community needs in project sustainability which in turn promotes a greater sense of ownership.

Participation is a rich concept that varies with its application. The way participation is defined also depends on the context in which it occurs. For some scholars, it is a matter of principle; for others a practice; and an end in itself (World Bank, 2003) indeed there is merit in all these interpretations as Rahnema (2005) noted.

According to Dannyet al. (2004), "Community participation is of absolute importance when it comes to community development" the two authors make it abundantly clear that this is more so in a situation where there is a physical outcome of the project that the community will have to take care of, Jenkins(Jenkins, 1999) "adds that this involvement is not always enough on its own, but that must be coupled with an element of capacity building along with creation of a plat form of negotiation between the state, private and voluntary sectors, and civil society.

The theoretical foundation of project management is made clear by the theory of project, the theory of management Nibyiza (2015) cited by Richardson (2018). These theories assume that when the beneficiaries or communities are actively involved in the design, implementation and management of projects, this will lead to their success and sustainability. This article supports these theories that support community involvement and participation in development projects and the article studies the causes of project failures in Africa, how bottom-up approach in planning, consultation, execution and monitoring with the communities can cause program survival, meet community needs and drive development in the area where the projects are taking place.

In most African countries, community participation in government development programmes and community ownership of these projects is still very lacking. The rationale for participation at local level systems form a recognition that involve people in government projects which makes everyone accountable for the budget and service deliveries in their area (Blair, 2002;Sirker and Cosic, 2007). These obligations are enshrined in most of the African constitutions, like in Uganda constitution but they are notfollowedwhen implementing these projects. The constitution of Uganda and reforms which have been carried out in the previous years have concentrated on decentralization of economic activities without even fiscal decentralization for example the finances of the Districts still remain with central Governments controlled by the Ministry of Finance: Even most of the money that come from the Central government is conditional grant and does what the Central government commands. This is the most similar to the colonial period when citizens were not given chance to participate in their economic activities.

In Uganda, citizen participation gears more efforts towards political decentralization with the enactment of the resistance Councils into corporate bodies with responsibility for service provision, and to delegate broad policy-making and planning powers to local councils. The 1993 Local Government (Resistance Councils) statute (LGS) and the 1997 Local Government Act (LGA) further strengthened districts by devolving more planning powers, which in theory meant that they ceased to be dejure arms of central government. These institutional reforms were further bolstered by the promulgation of the constitution of 1995 (in between the LGS 1993 and LGA 1997), which enshrined citizens' participation in planning and governance of the country. Within the section on national objectives, the constitution states: "The state shall be based on democratic principles, which empower 
and encourage the active participation of all citizens at all levels in their own governance. The state shall be guided by the principle of decentralization and devolution of government functions and powers to the people at appropriate levels where they can best manage and direct their own affairs". But unfortunately, this is not being done in Uganda.

\subsection{Statement of the Problem}

In recent years, there have been increasinginterests in participatory approaches, which have been developed to improve the well-being of communities and to make the development programs more effective, more successful and sustainable. In addition, there is evidence that development efforts which involve beneficiaries (communities)in the development projects at the beginning of the programmes make these programmes more successful than those which do not (Chambers, 2012).

In Africa, most of development programs are planned and implemented without community participatory approach, leading to failure of some of these programmes. In 1980's and 1990's, lots of projects in Nigeria and Uganda became "white elephants." In Uganda, Lira spinning mill in Northern Uganda and Lake Katwe salt project in the Western Uganda are good examples. These are projects which died a natural death. During this period, official development aid funds for community development projects arose. Too much aid led to aid dependency which was the only source of finance. This was not sustainable because funds were not used to address community problems including reducing poverty. The projects were not owned and sustained by the local population and therefore could not survive beyond the exit of donors despite huge amounts of money spent on implementation of these projects. For example Uganda still exports more than 500,000 metric tons of cotton to all over the world and imports nearly one million tons of textiles to its people. That's why we say that developing countries produce what they cannot consume and consume what they cannot produce.

According to Igboeli (1992), no matter the level of technical and financial assistance offered to selfhelp groups, the members should share actively in the decision to undertake certain projects. That is, rather than imposing development projects on a community, its members should be allowed to participate meaningfully in the planning and execution. Development is meaningless if it does not harness the potentials of the beneficiaries who are the primary stakeholders. It is therefore important to find out what ways the people think they can participate in the process of achieving their vision. We should move from bringing government close to people but bringing people close to government. In other words, it is high time we imbibe the culture of bottom-up approach to development planning; otherwise, development may be a mirage or "white elephants." The fact of the failure of many government projects and even the plethora of abandoned projects is a big problem and the basis for this article.

\subsection{Objective of the Study}

The main objective of this article is to examine the extent to which community participation contributes to success and sustainability of development programmes in LDCs Africa. The article analyzes the benefits of community participation and how this leads to sustainable development programmes, higher programmes outcomes, better services and non-responsive projects to the needs of the people. Most successful programmes world over, use bottom-up approach to determine priorities and then accurately reflect community needs in programme design with promising sustainability results and in turn promotes a greater sense of ownership and success.

In support of bottom-up approach, the researcher and many authors talk about Community Based Development (CBD) and Community Driven Development (CDD). Various studies by the World Bank and other international development institutions such as the independent organizations (NGOs) have also shown increase support and contribution to participatory approaches in enhancing community participation in development programmes that meet the needs of the poor.

\section{LITERATURE REVIEWS}

There are two ways communities participate in development projects according to Ghazalaand Vijayendra (2003), Community Based Development (CBD) and its more recent variant, Community Driven Development (CDD), are among the fastest growing mechanisms for channeling development assistance. To clarify concepts', CBD is an umbrella term that refers to projects which actively include beneficiaries in their design and management. CDD is a term, originally coined by World 
Bank that refers to CBD projects where communities have direct control over key projects as well as the management of investment funds.

According to Asia Development Bank Publication (2009), Community-Driven Development (CDD) refers to an approach in development projects whereby investment funds or resources are disbursed directly to communities. These funds are then used to design, implement, operate, and maintain infrastructure and associated services. Communities themselves set priorities with the help of governments, donors, consultants, technical advisors, facilitators, and Non-Governmental Organizations' (NGOs) (Green, 2008).

Conceptually, the key assumption of the CDD approach is that communities know what is best for them, and if properly guided making. Economic theory and CDD approach proponents suggest that outcomes are likely to be more relevant, effective, and sustainable with more top-down approaches or arrangements involving government officials or outside experts who are not directly affected by infrastructure intervention. CDD is considered as subset of the much broader Community Based Development (CBD) approach, which encompasses a wide range of projects that actively include beneficiaries in their design, management, and implementation. The level of community participation in $\mathrm{CBD}$ projects can vary, from simple information sharing, to social, economic and political empowerment of community groups.

Various studies by the World Bank and other international development institutions, as well as independent organizations, have also shown the immense contribution of such participatory approaches in enhancing the sustainability of small-scale infrastructure and in ensuring the responsiveness of sub projects to the needs of the poor.

\subsection{Project Ownership and Control}

Participation plays major role in people's management of their own affairs. Ownership and control of resources have a profound impact on participation in development projects (Danny et al., 2004).Uphoff (1998) emphasized four areas to be worked toward a participatory resource management program: greater economic and social equality, better access to services for all, greater participation in decision making and deeper involvement in the organizing process resulting from the empowerment of people.

\subsection{Sharing Benefits}

It is evident that without sharing the benefits of the project, participation is a frustrating process for the poorer people. Davids et al. (2005) noted that there should be a fair and equitable distribution of benefits as well as redistribution of goods and services, to enable poorer people to get a fairer share of society's wealth and to participate fully in the development process.

The Centre on Integrated Rural Development for Asia and the Pacific (CIRDAP, 1984), a regional rural development organization in south Asia, mentions that participation entails three district process. First, the involvement of the people in decision making; second eliciting of their contribution to development programs and third, their participation in sharing the benefits from the development process.

\subsection{Partnerships}

Partnership in development process allows stakeholders to work, talk and participate in solving problems with individuals who are often perceived as masters. Instead of demonstrating the relationship as a worker-client tie, the parties involved should agree on working in partnerships. An expression used by the Latin American activists to describe their relation with the people (communities, groups) with whom they are working is accompaniment or "accompanying process" (Wideman, 2001). Wilson and Whitmore identified a set of principles for collaboration in a variety of settings and situations. These include non-intrusive collaboration, mutual trust and respect, a common analysis of what the problem is a commitment to solidarity, equality in the relationship, and an explicit focus on process.

\subsection{Why Community Must Be Involved in Projects that Affect Them?}

Having enjoyed so much working and living together, having enjoyed each other's confidence and relationships, having collaborated for so long to achieve common objectives, having sat together to 
jointly take decisions for their common goals and benefits, it is logical and reasonable to think that any attempt at breaking this bond would be minimally resisted or maximally broken and destroyed. No wonder then the failure of many government projects that has no elementsof community participation.

Government officials in developing countries in their wisdom and for whatever reason they deemed fit, established projects in communities without consultation (idea generation and mode of implementation) with the rural communities as a result many of the projects fail and abandon. For example in Nigeria the Directorate for Food, Roads and Rural Infrastructure (DFRRI) no doubt did many great jobs around the country. It opened up roads, dug bore holes, provided rural electrification and even ventured into shelter. Many of them however failed eventually. To put it in words of Stanley (2003), "A Presidential Inspection Team to some of the projects reported back that DFFRI roads were over grown with grasses and boreholes (even when they worked) were unkempt and that they asked the communities where these facilities were cited, why the unholy situation of things, they reported that they had not been involved in the process and therefore could not organize for their maintenance."

What they said was that they just woke up one morning and saw heavy machines making roads which they appreciated, but that was the end of it. Many projects have lost their functional utility. The lesson of this therefore is that people must be involved as participants if there is to be any sustainability. Since the people are the beneficiaries of development plans and projects, they have a stake; they must be partners in that process. They must be key participants whose views, choices, needs and feelings must be taken into account if we are to have a sustainable development.

According to Chambers (2012), community participation undergoes four stages as given below:

Involvement:This includes information, education and planning (IEP) to provide adequate and timely evidence, educate people about the development initiative, and outline a plan of action.

Control: This encompasses implementation, co-ordination and monitoring (ICM). In this stage it is assumed that once local people are well informed about a particular development initiative, they are in a better position to plan on their own and implement project activities.

Ownership: This stage assumes that local people share project costs-if not by contributing money, then in kind by offering time, materials or other efforts. This sharing of costs is assumed to engender a sense of ownership and commitment to the project.

Feedback:This stage includes consultation to harness local people's knowledge and experiences reassess their needs and evaluate outcomes of a development project. It also holds local people accountable for successes and failures.

In this model, therefore, community participation in development projects is hypothesized to be effective by involving local people in all stages. Chambers (2012) contends that each stage is the result of a set of elements that emerges from the views, opinions, and perspectives of the stakeholders. Further, although elements in the model are seen as different stages, in practice they are often interrelated and interwoven (Chambers, 2012). The model further assumes that community participation is a keytool for collecting indigenous knowledge and promoting social change in communities.

The cornerstone of community based development initiatives is the active involvement of members of a defined community in at least some aspects of project design and implementation. When potential beneficiaries also make key projects decisions, participation becomes self-initiated action-what has come to be known as the exercise of voice and choice of empowerment.

The benefits among others according to Arthur and Michelle (2002) are;

* It will lead to better designed projects.

* Better targeted benefits.

* It is more cost effective.

* It will lead to more equitable distribution of project benefits

* It will lead to less corruption. 
* It strengthens the capabilities of the citizenry to undertake self-initiated development activities.

* It improves the match between what a community needs and what it obtains. This is because the project will be more consistent with the preference of the target group. In conclusion, Chandan (2014) said the current emphasis is on communities participating in the project that affect them.

Decades of spending billions of dollars to eradicate poverty in Africa have given minimal results with over 300 million people in Africa living below less than $\$ 1$ a day. These people are completely alienated, disempowered and vulnerable despite lots of aids given to Africa.

World Bank evaluation of projects indicated that those projects that have community participation have succeeded and were rated satisfactory. "Achieving Project Sustainability through Community Participation" (Olukotun, 2017).

According to the World Bank (2003), "In 1968, a community of 2000 people in Malawi started work on novel water supply system. Community members began the planningand construction and operation of their own water supply and distribution. Field staff for the project was recruited locally, traditional community groups formed the basis for water communities, and government support was limited. Virtually, all of the more than 6000 standpipes installed nationwide are still in working order. More than 1 million Malawians have high quality, reliable and convenient water through systems that they themselves built, own and maintain. An analysis of rural and urban development over thirty years found high correlation between Project Performance and level of participation.

The bank concluded by saying that a survey of 25 World Bank agricultural projects evaluated.Five to ten years after completion found that participation was an important determinant in project performance and sustainability. In the evaluation of another World Bank project, it was also found out that during a ten year period in the Philippines, the National Irrigation Administration shifted from a top down government approach to heavy reliance on local farmers in the design, operation and maintenance of local irrigation systems. It was discovered that the canals and structures worked better, rice yields were 20\% higher and the irrigated area 35\% greater than in control groups without participation (World Bank, 2003) on the evaluation of community development projects funded by the Agha Khan Rural Support Programme in Northern Pakistan, it was found out that community managed projects are better maintained than the projects managed by the local Government.

For projects to be sustainable there must be community participation. This is because according to Blair (2002), through participation, the community develops skills for collective action, maintenance and sustainability of the projects.

\subsection{There Are Conditions for Achieving Sustainability Through Community Participation:}

Having seen the need for communities to participate in the conception, design and implementation of projects that affects them in order to achieve sustainability, there are certain conditions that must be fulfilled for the sustainability to be achieved. The first condition for achieving sustainability through community participation is that there must be government support (state or local). This is because, according to Olukotun (2017), local government arouses local citizens to contribute financially to the management of local affairs or participate on a voluntary basis with in community development committees engaged in self-help projects. The assistance from the government can be in cash or in kind. For instance, after the completion of a project like a school or health center, a community would normally need teaching and non-teaching staff and also health workers. The community may not be in a position to provide them except with government support.

According to Arthur and Michelle (2002), even if communities are initially successful in creating the project, they may lack the material resources and connections to sustain their efforts. Therefore, the need for well-functioning state apparatus does not disappear with active community involvement must therefore lobby for continuing support for inputs and training so that they can sustain such projects. Put differently, Chambers (2012) said that beneficiary communities often too poor to fund own teachers, doctors, desks and medicine remain in need of government support for inputs, maintenance investment and trained staff to sustain project benefits. Thus, the need for a responsive state apparatus may increase when community participation projects are implemented. In his own contribution, Chandan (2014) in an in-dept study of tank management in India found that maintenance of community infrastructure is crucially dependent on external agents working with the local communities. 


\section{CONCLUSION}

The need to making participation work therefore is to create forms of downward and upward accountability and simultaneously to maintain close links between the higher levels of government and the community where projects are being implemented.

In order to ensure community participation on projects' success, community leaders must accept the challenges for project sustainability. The leaders must be out rightly be accountable and answerable to beneficiaries rather than to political and bureaucratic superiors (Arthur and Michelle, 2002). Their records should be well kept in simple language and accessible to every members of the community. The leaders should be transparent in their dealing with members of the community and call for regular meetings where the people are briefed on the progress and sustainability efforts of the community and the challenges ahead.

Lastly, the sustainability of community based projects depends crucially on an enabling institutional environment, which requires Uganda government commitment and on the accountability of leaders to their communities and their involvement right from the commencement of projects in their area to successful completion.

\section{REFERENCES}

[1] Adnan S., Barrett A., NurulAlam S.M. and Brustinow A. (1992). People's Participation: NGOs the Flood Action Plan. Research and Advisory Services, Dhaka.

[2] Arthur, A. S. and Michelle, R. D. (2002). Community Involvement: Theoretical Approaches and Educational Initiatives. Wiley-Blackwell Publishers. ISBN: 978-1-405-10793-8.

[3] Blair, H. (2000). Participation and Accountability at the Periphery: Democratic Local Governance in Six Countries. World Development. Volume. 28, Issue 1, pp21-39.

[4] Chambers, R. (2012). Provocations for Development. Bourton on Dunsmore: Practical Action Publishing.

[5] Chandan, K. P. (2014). Practicing Participatory Rural Appraisal - A Comprehensive Approach for Learning from the People. Advances in Extension Education and Rural Development. Volume II. India: Agrobios.

[6] Chirenje L. I., Giliba R. A. and Musamba, E. B. (2013). Local Communities' Participation in Decision Making Processes through Planning and Budgeting in African Countries. Chinese Journal of Population Resources and Environment. Volume 11, Issue 1. Pp $10-16$.

[7] Danny B., Frances H., Marilyn T., Pete W. and Mandy W. (2004). Making community participation meaningful: A handbook for development and assessment. Published for the Joseph Rowntree Foundation by The Policy Press. England.

[8] Davids I., Theron F. and Maphunye, K. (2005). Participatory Development in South Africa: A Development Management Perspective. Pretoria, South Africa: Van Schaik Publishers.

[9] Ghazala, M. and Vijayendra, R. (2003). Community Based and Driven. Development: A Critical Review Development Research Group. The World Bank Development.

[10] Green K.O. (2008).A Seat at the Table: A Study of Community Participation in Two Healthy Cities Projects: Critical Public Health. Volume 18. Issue 3. https://doi.org/10.1080/09581590801959337.

[11] Hussein, A. (2013). Determinants of Community Participation in the Implementation of Development Projects: A Case of Garissa Sewerage Project. University of Nairobi.

[12] Igboeli, M.O. (1992). "Self-help as a Strategy for Rural Development: A Critique" in Olisa, M.S.O. and Obiukwu, J. I. (eds), Rural Development in Nigeria: Dynamics and Strategy. Awka: Makslink Publishers.

[13] Jenkins, P. (1999). Difficulties Encountered in Community Involvement in Housing Delivery under the New South African Housing Policy: Habitat International. Volume 23, No. 4,pp432-446.

[14] Kleemeier,E. (2000). The Impact of Participation on Sustainability: Analysis of the Malawi Rural Piped Scheme Programme.

[15] Nibyiza, F. (2015). Analysis of Project Scope Change Management. Tool for Project Success Case Study of AkaziKanoze Projects. Kenya.

[16] Olukotun, G. A. (2017). Achieving Project Sustainability Through Community Participation. Journal of Social Sciences. Volume 17, Issue 1, pp 21-29.

[17] Rahnema, M. (2005). Designing Community Based Development: Toward Environmentally and Socially Sustainable Development. Washington, DC: World Bank.

[18] Richardson, G. P. (2018). Using a Group Decision Support System to Add Value to Group Model Building. SystDyn Rev. Volume 26, Issue 4, pp 335-346. 
[19] Sirker, K. and Cosic, S. (2007). Empowering the Marginalized: Case Studies of Social Accountability Initiatives in Asia Public Affairs Foundation. World Bank Institute. India.

[20] Stanley, B. (2003). Sustainability through Participation. Minna, Nigeria: Dele Publishers.

[21] Stone, L. S. and Stone, T. M. (2010). Community-Based Tourism Enterprises: Challenges and Prospects for Community Participation; Khama Rhino Sanctuary Trust, Botswana. Journal of Sustainable Tourism. Volume 19, Issue 1. pp 197-114.

[22] Tade,P,(2001) Community Participation Ibadan: Adams publishers.

[23] Uphoff, N. (1998). Reasons for Success. Conneticut: Kumarlan Press.

[24] Wideman, M. (2001). Managing the Project Environment. A E W Services, Vancouver, B.C., Canada.

[25] World Bank (2003). World Development Report 2004 Making Services Work for the Poor, Washington DC, World Bank and Oxford University Press.

[26] Zillman D. N., Lucas A. R. and Pring G. (2002). Human Rights in National Resource Development: Public Participation in the Sustainable Development of Mining and Energy Recourse. Oxford: Oxford University Press.

Citation: George Stanley Kinyata (PhD), Nafiu Lukman Abiodun (PhD). "The Impact of Community Participation on Projects' Success in Africa: A Bottom Up Approach" International Journal of Research in Sociology and Anthropology (IJRSA), vol 6, no. 3, 2020, pp. 01-08. doi: https://doi.org/10.20431/24548677.0603001.

Copyright: (C) 2020 Authors. This is an open-access article distributed under the terms of the Creative Commons Attribution License, which permits unrestricted use, distribution, and reproduction in any medium, provided the original author and source are credited. 